\title{
Novel reassortant clade 2.3.4.4 avian influenza $A(H 5 N 5)$ virus in wild birds and poultry, Croatia, 2016-2017
}

\author{
Vladimir Savić*
}

Poultry Centre, Croatian Veterinary Institute, Zagreb, Croatia

\begin{abstract}
SAVIĆ, V.: Novel reassortant clade 2.3.4.4 avian influenza A(H5N5) virus in wild birds and poultry, Croatia, 2016-2017. Vet. arhiv 87, 377-396, 2017.
\end{abstract}

\section{ABSTRACT}

Highly pathogenic avian influenza (HPAI) causes flock mortality as high as $100 \%$ in susceptible poultry species but it also poses a threat for humans, particularly viruses of A/goose/Guangdong/96-like (GD/96) lineage. The emergence of novel HPAI viruses in migratory birds is of concern because of the potential for virus spread during migration. In late 2016, novel GD/96 reassortant clade 2.3.4.4 group B avian influenza H5N5 virus was detected in wild birds and domestic poultry in Croatia, concurrently with numerous detections of $\mathrm{H} 5 \mathrm{~N} 8$ virus of the same clade and group. Sequencing of the full genome of the H5N8 index case isolate (October 2016) and of all three H5N5 isolates (December 2016 -March 2017) has shown that the novel H5N5 reassortant virus most likely emerged as a result of complex reassortment process in Asia from HPAI H5N8 viruses after the later viruses have became established in wild bird population. Concurrent findings of both, H5N5 and H5N8 viruses, at the same locations in Croatia indicate that the H5N5 reassortant virus was introduced from Asia as a subpopulation of $\mathrm{H} 5 \mathrm{~N} 8$ viruses by the same wild bird flyways. Although the novel H5N5 reassortant virus possesses haemagglutinin of the GD/96 lineage, the virus genome has typical avian virus traits. Apart from mutations T215A in M1 protein and P42S in NS1 protein which are associated to increased virulence in mice, none of the mutations related to increased affinity to human-type $(\alpha-2,6)$ receptors and mammalian host adaptation were found. Nevertheless, the virus poses a serious threat to the poultry industry since high pathogenicity for gallinaceous birds was confirmed by high intravenous pathogenicity index (2.87).

Key words: influenza, HPAI, H5N5, reassortant, full genome sequence

\section{Introduction}

Highly pathogenic avian influenza (HPAI) causes flock mortality as high as $100 \%$ in susceptible poultry species (ALEXANDER and CAPUA, 2008) but it also poses a threat

\footnotetext{
*Corresponding author:

Vladimir Savić, DVM, PhD, Poultry Centre, Croatian Veterinary Institute, Heinzelova 55, 10000 Zagreb, Croatia, Phone: +385 12440 210; Fax: +385 12441 396; E-mail: v_savic@veinst.hr
} 
for humans, particularly H5N1 viruses of A/goose/Guangdong/96-like (GD/96) lineage (NEUMANN et al., 2010). Since 2003, the GD/96 lineage viruses have been evolving into diverse clades and subclades (WHO-OIE-FAO, 2014), most of them emerging in Asia. During the evolution of HPAI H5N1 viruses, reassortment events involving the 6 internal gene segments have often been detected, but novel subtypes (i.e., combinations of HPAI H5 with other N subtypes) have rarely been isolated (DE VRIES et al., 2015). Unlike other GD/96 clades, a new clade designated 2.3.4.4 (WHO, 2015) comprises of several other H5Nx subtypes. HPAI H5N5 virus (A/duck/Guangdong/wy24/2008) is the first detected reassortant subtype within this clade. Subsequent reassortment events between viruses harbouring a hemagglutinin (HA) segment originally derived from clade 2.3.4.4 H5N5 viruses and a range of other avian influenza viruses have generated the H5N2, H5N6, and H5N8 subtypes (DE VRIES et al., 2015).

The H5N8 subtype reassortants, which probably originated in eastern China, caused outbreaks in wild birds and poultry in South Korea in January 2014 (LEE et al., 2014). These H5N8 outbreaks were caused by 2 distinct virus groups: group A (Buan-like) and group B (Gochang-like). Similar to the spread of H5N1 viruses by wild birds in 20052006 from Asia to Europe, the Middle East, and Africa during the course of a few months (OLSEN et al., 2006), the Buan-like H5N8 viruses rapidly spread worldwide in 2014-2015 reaching also North America (LEE et al., 2015). Subsequent reassortment of these Eurasian origin $\mathrm{H} 5 \mathrm{~N} 8$ viruses with North American low pathogenic avian influenza (LPAI) viruses occurred generating intercontinental clade 2.3.4.4 group A reassortants H5N1 and H5N2.

In May and June 2016, a new triple reassortant of clade 2.3.4.4 group B H5N8 HPAI virus caused die offs in migratory wild birds at both the Qinghai Lake in China and around Uvs-Nuur Lake (Tyva Republic) at the Russia-Mongolia border. The new reassortant contained only 3 gene segments: HA, neuraminidase (NA) and non-structural (NS) of the Gochang-like viruses, while the other five segments originated from LPAI viruses usually found in Mongolia and China (LEE et al., 2017; LI et al., 2017). The reassortment process in wild migratory birds appears to have been a complex process and was likely completed in early 2016 (LI et al., 2017). In November 2016, outbreaks among wild birds and domestic poultry in Germany were also caused by clade 2.3.4.4 group B H5N8 HPAI viruses similar to that from Russia-Mongolia border, but two gene segments, polymerase acidic (PA) and nucleoprotein (NP) were clearly distinguishable indicating that viruses found in Germany were further reassortants (POHLMANN et al., 2017). H5N8 HPAI viruses were also detected in most of the other European countries in 2016-2017. During the same period of time a smaller number of H5N5 HPAI viruses infecting wild birds and poultry were also detected in several European countries.

So far, no human cases of H5N8 virus infection have been reported despite large numbers of people being occupationally exposed while managing the avian outbreaks and 
the risk for humans is considered very low (ARRIOLA et al., 2015). Nevertheless, clade 2.3.4.4 H5N5 viruses from China have been shown to bind to human-type receptors, transmit efficiently in guinea pigs and might be multiple-resistant to antiviral agents (ZHAO et al., 2013; LI et al., 2015).

The aim of this study was to characterise three $\mathrm{H} 5 \mathrm{~N} 5$ viruses isolated from wild birds and poultry in Croatia in 2016-2017 and to compare them to earlier clade 2.3.4.4 H5N5 HPAI viruses from Asia as well as to recent H5N5 and H5N8 HPAI viruses from Asia and Europe in order to elucidate their epidemiological link, reassortment event, mutations related to possible risk for public health and pathogenicity for poultry.

\section{Materials and methods}

Samples. Suspicious and dead wild birds as well as poultry that were submitted to the National Reference Laboratory for Avian Influenza within passive monitoring were tested for presence of avian influenza (AI) viruses using standard molecular methods. Samples from each AI H5 outbreak were subjected to virus pathotyping. Four representing samples: H5N8 index case virus A/mute swan/Croatia/70/2016 (Swn70-H5N8) and each virus isolate of three $\mathrm{H} 5 \mathrm{~N} 5$ cases were subjected to further analysis. The representative samples are listed in Table 1.

Virus isolation, antigenic subtyping and pathogenicity assessment in chickens. Virus isolates were obtained after the first passage in 11-day old embryonated eggs from a specific pathogen free (SPF) chicken flock. HA and NA subtypes were determined using haemagglutination and neuraminidase inhibition tests. Intravenous pathogenicity index (IVPI) for H5N5 index case virus A/mute swan/Croatia/102/2016 (Swn102-H5N5) was assessed in ten 6-week-old SPF chickens. All these tests were conducted according to the recommendation of the World Organization for Animal Health (OIE, 2015).

Molecular methods and phylogenetic analysis. Viral RNA was extracted from various tissues as well as oropharingeal and cloacal swabs using High Pure Viral Nucleic Acid Kit (Roche Applied Science, Mannheim, Germany). Reverse transcription quantitative PCR (RT-qPCR) for AI M gene and H5 gene was carried out according to methods of SPACKMAN et al. (2002) and SLOMKA et al. (2007a), respectively. For detection of AI N8 gene, in house RT-qPCR was used (details available on request). Detection of AI N5 gene was carried out according to method of FEREIDOUNI et al. (2009). For initial determination of the HA cleavage site of detected H5 viruses, conventional reverse transcription PCR (RT-PCR) using KHA primers (SLOMKA et al., 2007b) with subsequent nucleotide sequencing was carried out. For amplification of the full-length gene segments, RNA extracted from brain tissue was used since it gave lowest $\mathrm{Cq}$ value in RT-qPCR tests. For this purpose conventional reverse transcription PCR (RT-PCR) according to HOFFMANN et al. (2001) and LI et al. (2007) was used with some modifications available 
on request. All PCR products were electrophoresed in 2\% agarose gel and specific bands were excised and purified with Wizard SV Gel and PCR Clean-Up System (Promega, Madison, WI). Sanger sequencing of all PCR amplicons was performed in both directions with Big Dye Terminator v3.1 Sequencing Standard Kit (Applied Biosystems, Foster City, CA) in an ABI3730XL DNA sequencer (Applied Biosystems) and with same primers used for PCR. After sequencing, the raw nucleotide sequences were assembled and the primer sequences were trimmed off. Each nucleotide sequence of the H5N8 index case and the H5N5 index case viruses was queried online against the nucleotide sequence databases in GenBank and in the Global Initiative on Sharing All Influenza Data (GISAID). Maximum likelihood phylogenetic analysis of all 8 genes was conducted and the evolutionary analyses performed by using MEGA7 (KUMAR et al., 2016). Nucleotide sequences of the HA gene were also translated into amino acid sequences to predict pathogenicity of each analyzed isolate according to the HA0 cleavage site. To investigate the potential zoonotic affinity of Croatian H5N5 viruses, sequence data was compared with the H5N1 genetic changes inventory at the US Centers for Disease Control and Prevention (CDC, 2012) to identify single or collective mutations that might influence viral phenotypic characteristics of importance and may indicate adaptation to mammalian species or alter susceptibility to antiviral drugs.

Sequences were deposited into the GISAID EpiFlu database (Table 1).

Table 1. Representative isolates of highly pathogenic avian influenza subtype H5 virus outbreaks in Croatia from October 2016 to March 2017 used for full genome sequencing and phylogenetic analysis

\begin{tabular}{|l|c|c|c|c|}
\hline $\begin{array}{l}\text { Sample } \\
\text { collection date }\end{array}$ & Location & Virus designation & Subtype & $\begin{array}{c}\text { GISAID } \\
\text { Accession }\end{array}$ \\
\hline 31 Oct 2016 & Cerna & A/mute swan/Croatia/70/2016* & H5N8 & EPI_ISL_238196 \\
\hline 27 Dec 2016 & Crkveni Bok & A/mute swan/Croatia/102/2016* & H5N5 & EPI_ISL_240101 \\
\hline 20 Jan 2017 & Kozjak (Bilje) & A/mute swan/Croatia/42/2017 & H5N5 & EPI_ISL_243698 \\
\hline 7 Mar 2017 & Špićkovina & A/chicken/Croatia/104/2017 & H5N5 & EPI_ISL_261332 \\
\hline
\end{tabular}

*Virus isolated during index case for particular H5 subtype

\section{Results}

From October 2016 until March 2017, 19 outbreaks of HPAI H5N8 and three outbreaks of HPAI H5N5 were detected in wild birds and poultry in Croatia (Fig 1.). The HPAI H5 viruses were most commonly found ( $83.3 \%$ of all wild bird cases) in mute swans (Cygnus olor), and H5N8 virus was also detected in greylag geese (Anser anser) and great cormorants (Phalacrocorax carbo). In all wild bird cases, the HPAI H5 viruses were found exclusively in dead animals. In poultry, three H5N8 and one H5N5 case 
were detected. Three cases (two H5N8 and one H5N5) occurred in backyard poultry with mixed bird species comprising of at least ducks and chickens while one case occurred in a small breeder duck flock housed in a semi-confined premise. Contact with wild water birds was reported in all poultry cases.

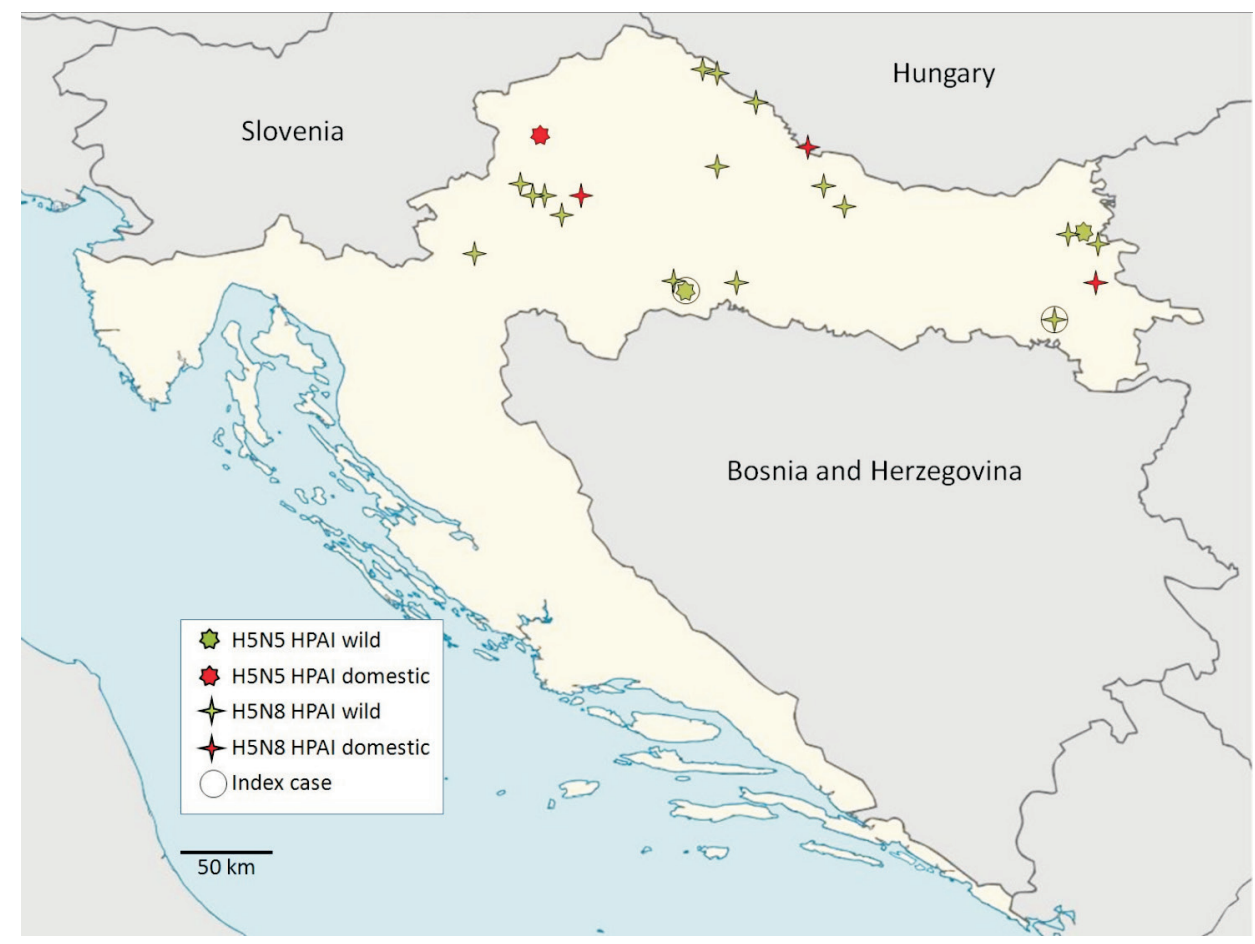

Fig. 1. Locations of highly pathogenic avian influenza (HPAI) H5 outbreaks in poultry and wild birds in Croatia from October 2016 to March 2017.

In all HPAI cases, the deduced HA cleavage site of the H5 virus was PLREKRRKR/ GLF, indicating high pathogenicity for gallinaceous birds. AI subtype of four representative samples (Table 1) was also confirmed using haemagglutination and neuraminidase inhibition tests. The IVPI of AI virus isolated during the H5N5 index case (Swn102H5N5) was 2.87. 
Comparison of sequence data of Croatian H5N5 viruses with the H5N1 genetic changes inventory $(\mathrm{CDC}, 2012)$ identified a total of 3 point mutations among 104 single or collective mutations that might influence viral phenotypic characteristics of importance and may indicate adaptation to mammalian species, or alter susceptibility to antiviral drugs (Table 2).

Table 2. Genetic mutations identified in three highly pathogenic avian influenza (H5N5) virus isolates from wild birds and poultry in Croatia, 2016-2017, that might result in phenotypic consequences $^{1}$

\begin{tabular}{|l|l|l|}
\hline Protein & amino acid position/motif & Phenotypic consequences $^{2}$ \\
\hline HA & $323-330(\mathrm{R}-\mathrm{X}-\mathrm{R} / \mathrm{K}-\mathrm{R})$ & $\begin{array}{l}\text { Polybasic cleavage motif sequence required for high } \\
\text { pathogenicity }\end{array}$ \\
\hline M1 & T215A & Increased virulence in mice \\
\hline NS1 & P42S & Increased virulence in mice \\
\hline
\end{tabular}

${ }^{1}$ Phenotypic consequences may include an influence on viral phenotypic characteristics of importance, adaptation to mammalian species, or altered susceptibility to existing antiviral drugs. H5N1 numbering based on the mature HA protein relative to A/Vietnam/1203/2004. HA, hemagglutinin; M, matrix; NS, nonstructural. ${ }^{2}$ The mutation to the right of the amino acid position confers the phenotypic consequence described.

Phylogenetic trees for each gene segment of four representing samples are shown in Figs 2-9. 
V. Savić: Novel reassortant clade 2.3.4.4 avian influenza H5N5 virus in Croatia, 2016-2017

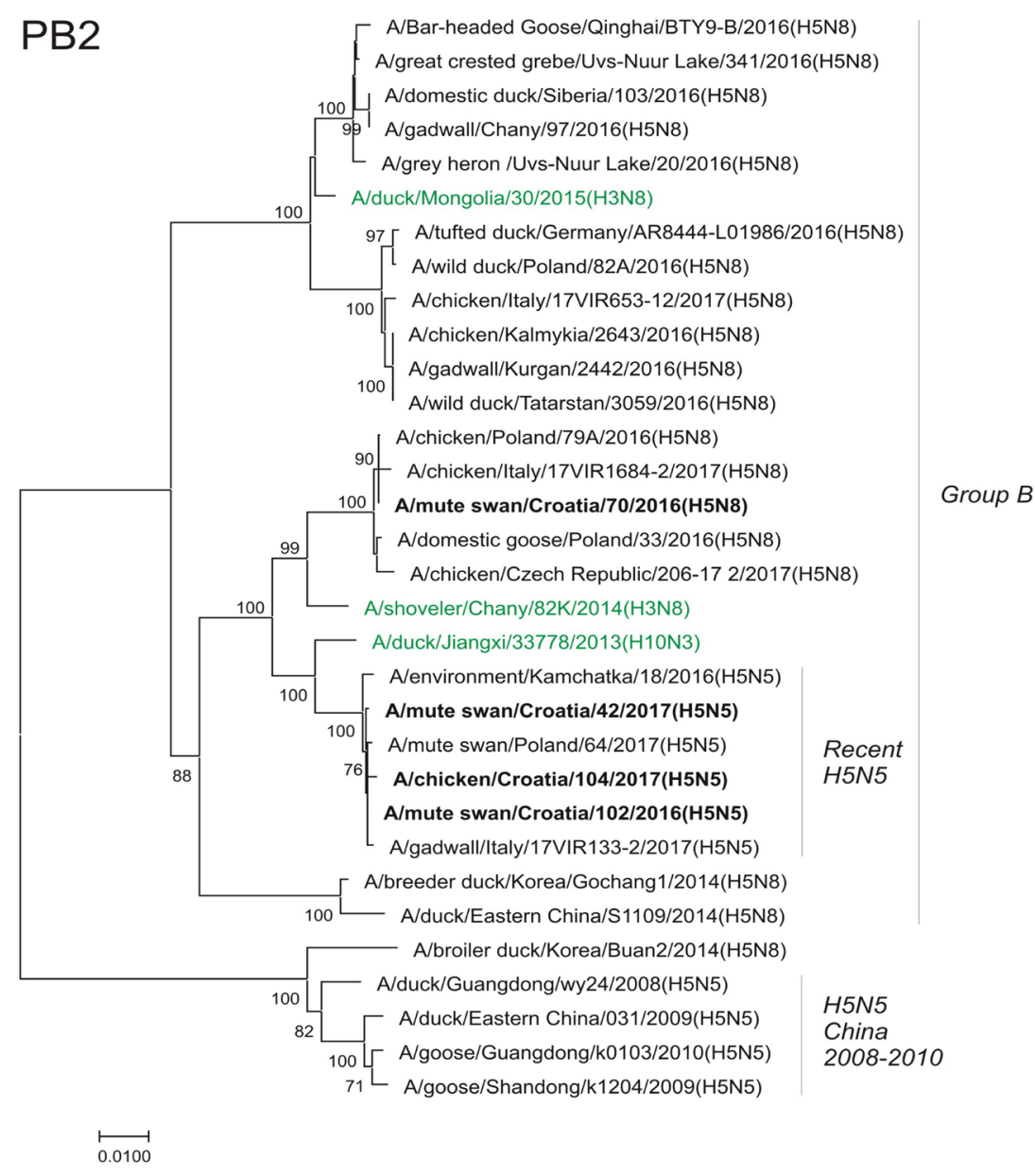

Fig. 2. Phylogenetic analysis of polymerase basic-2 (PB2) gene segment for avian influenza virus isolates from Croatia and reference isolates of lineage A/Goose/Guangdong/1/96 clade 2.3.4.4 and related low pathogenic avian influenza viruses (LPAIV). LPAIV are indicated in green. Influenza virus sequences from Genbank and the GISAID EpiFlu ${ }^{\mathrm{TM}}$ database were used for comparison. Viruses that were sequenced in this study are indicated in bold. The evolutionary history was inferred using the Neighbor-Joining method in MEGA7 (KUMAR et al., 2016). The percentage of replicate trees in which the associated taxa clustered together in the bootstrap test (1000 replicates) are shown next to the branches $(>70 \%)$. The evolutionary distances were computed using the Maximum Composite Likelihood. Scale bar indicates nucleotide substitutions per site. 


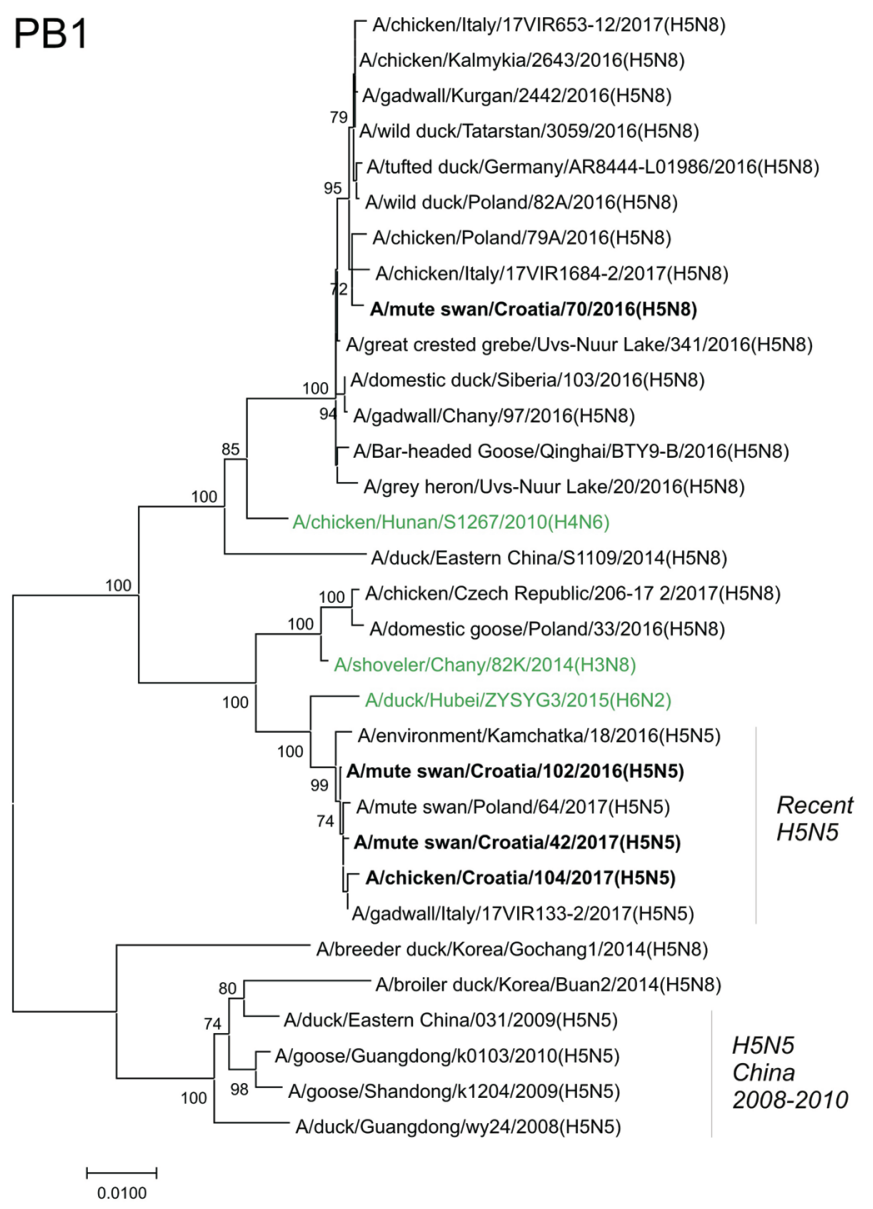

Fig. 3. Phylogenetic analysis of polymerase basic-1 (PB1) gene segment for avian influenza virus isolates from Croatia and reference isolates of lineage A/Goose/Guangdong/1/96 clade 2.3.4.4 and related low pathogenic avian influenza viruses (LPAIV). LPAIV are indicated in green. Influenza virus sequences from Genbank and the GISAID EpiFlu ${ }^{\mathrm{TM}}$ database were used for comparison. Viruses that were sequenced in this study are indicated in bold. The evolutionary history was inferred using the Neighbor-Joining method in MEGA7 (KUMAR et al., 2016). The percentage of replicate trees in which the associated taxa clustered together in the bootstrap test (1000 replicates) are shown next to the branches $(>70 \%)$. The evolutionary distances were computed using the Maximum Composite Likelihood. Scale bar indicates nucleotide substitutions per site. 


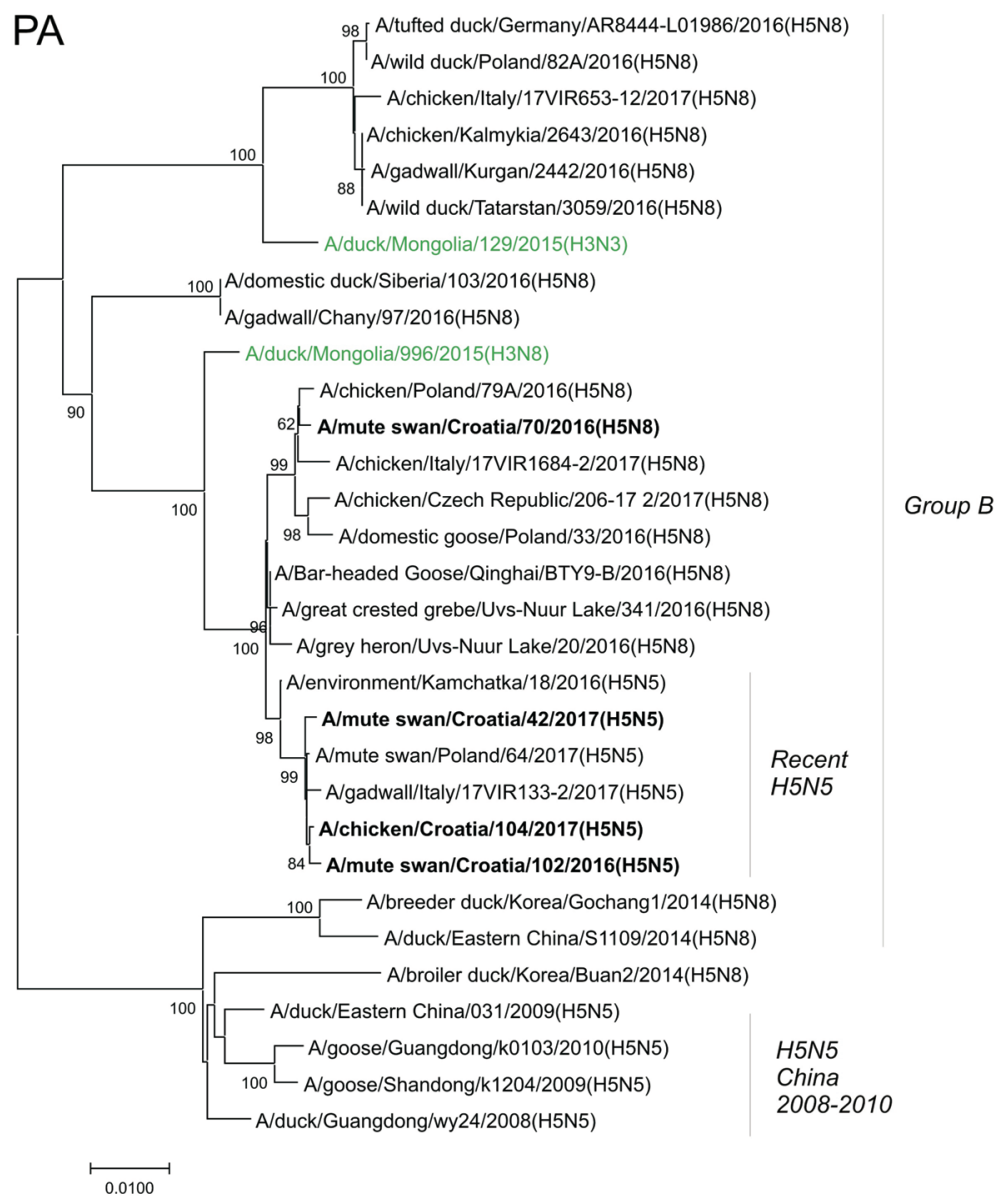

Fig. 4. Phylogenetic analysis of polymerase acidic (PA) gene segment for avian influenza virus isolates from Croatia and reference isolates of lineage A/Goose/Guangdong/1/96 clade 2.3.4.4 and related low pathogenic avian influenza viruses (LPAIV). LPAIV are indicated in green. Influenza virus sequences from Genbank and the GISAID EpiFlu ${ }^{\mathrm{TM}}$ database were used for comparison. Viruses that were sequenced in this study are indicated in bold. The evolutionary history was inferred using the Neighbor-Joining method in MEGA7 (KUMAR et al., 2016). The percentage of replicate trees in which the associated taxa clustered together in the bootstrap test (1000 replicates) are shown next to the branches (>70\%). The evolutionary distances were computed using the Maximum Composite Likelihood. Scale bar indicates nucleotide substitutions per site. 
V. Savić: Novel reassortant clade 2.3.4.4 avian influenza H5N5 virus in Croatia, 2016-2017

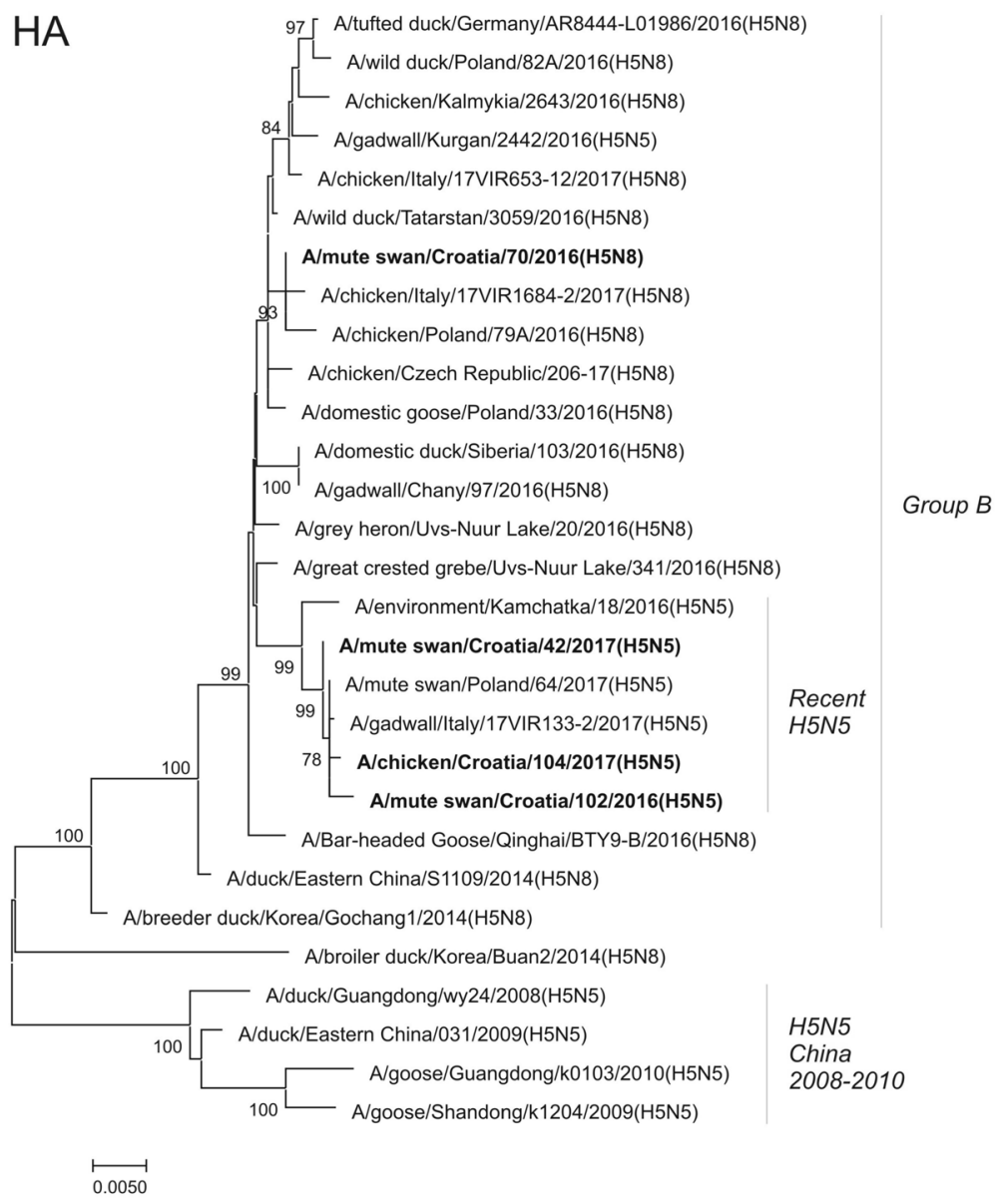

Fig. 5. Phylogenetic analysis of hemagglutinin (HA) gene segment for avian influenza virus isolates from Croatia and reference isolates of lineage A/Goose/Guangdong/1/96 clade 2.3.4.4.

Influenza virus sequences from Genbank and the GISAID EpiFlu ${ }^{\mathrm{TM}}$ database were used for comparison. Viruses that were sequenced in this study are indicated in bold. The evolutionary history was inferred using the Neighbor-Joining method in MEGA7 (KUMAR et al., 2016). The percentage of replicate trees in which the associated taxa clustered together in the bootstrap test (1000 replicates) are shown next to the branches $(>70 \%)$. The evolutionary distances were computed using the Maximum Composite Likelihood. Scale bar indicates nucleotide substitutions per site. 


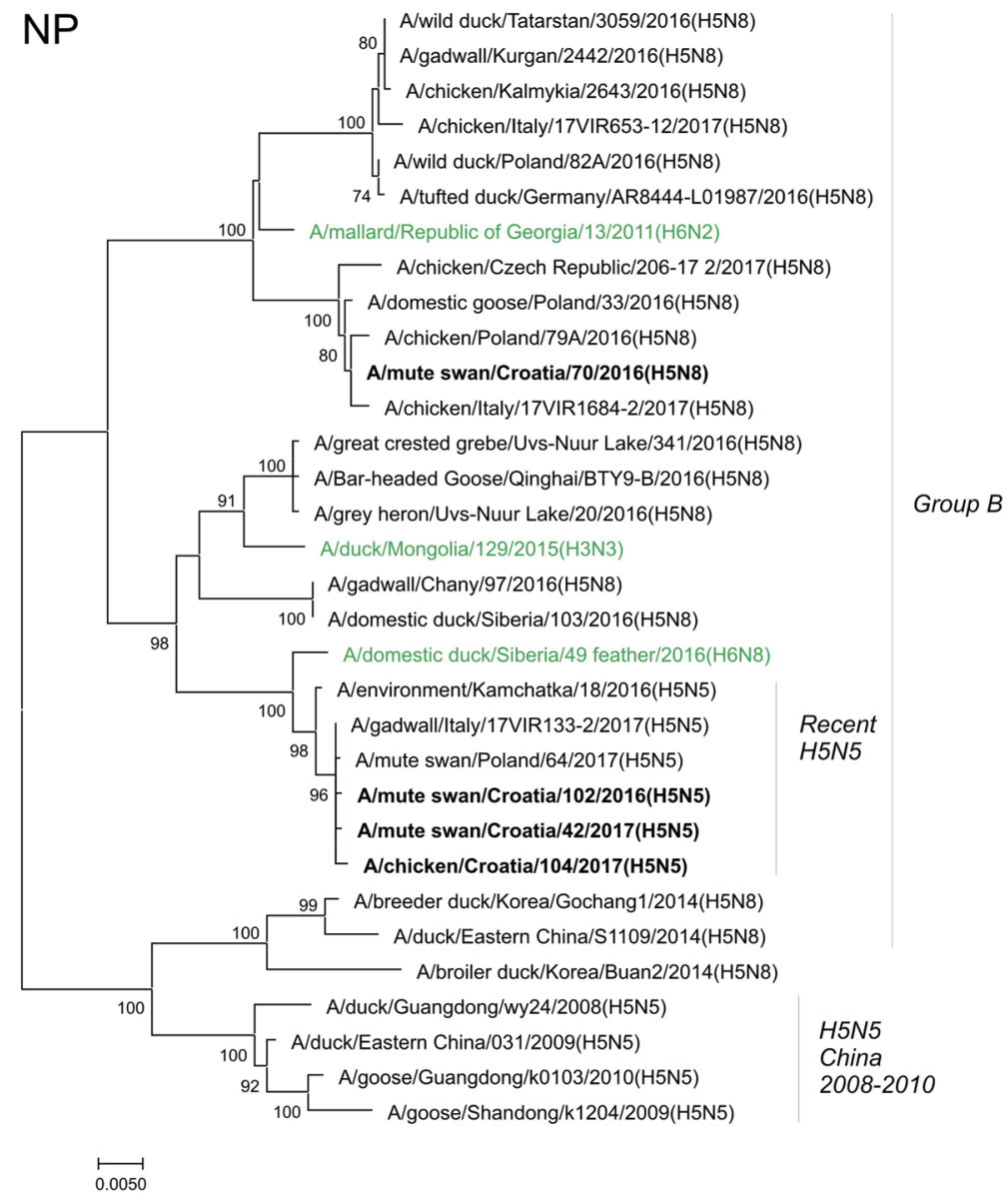

Fig. 6. Phylogenetic analysis of nucleoprotein (NP) gene segment for avian influenza virus isolates from Croatia and reference isolates of lineage A/Goose/Guangdong/1/96 clade 2.3.4.4 and related low pathogenic avian influenza viruses (LPAIV). LPAIV are indicated in green. Influenza virus sequences from Genbank and the GISAID EpiFlu ${ }^{\mathrm{TM}}$ database were used for comparison. Viruses that were sequenced in this study are indicated in bold. The evolutionary history was inferred using the Neighbor-Joining method in MEGA7 (KUMAR et al., 2016). The percentage of replicate trees in which the associated taxa clustered together in the bootstrap test (1000 replicates) are shown next to the branches $(>70 \%)$. The evolutionary distances were computed using the Maximum Composite Likelihood. Scale bar indicates nucleotide substitutions per site. 


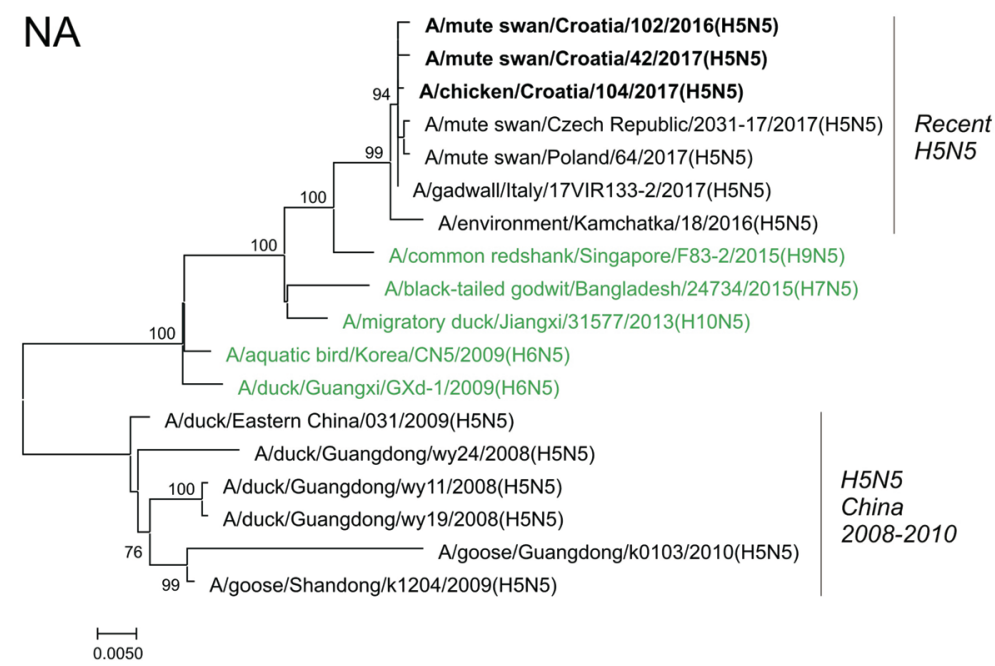

Fig. 7. Phylogenetic analysis of neuraminidase (NA) gene segment for avian influenza virus isolates from Croatia and reference isolates of lineage A/Goose/Guangdong/1/96 clade 2.3.4.4 and related low pathogenic avian influenza viruses (LPAIV). LPAIV are indicated in green. Influenza virus sequences from Genbank and the GISAID EpiFlu ${ }^{\mathrm{TM}}$ database were used for comparison. Viruses that were sequenced in this study are indicated in bold. The evolutionary history was inferred using the Neighbor-Joining method in MEGA7 (KUMAR et al., 2016). The percentage of replicate trees in which the associated taxa clustered together in the bootstrap test (1000 replicates) are shown next to the branches $(>70 \%)$. The evolutionary distances were computed using the Maximum Composite Likelihood. Scale bar indicates nucleotide substitutions per site. 


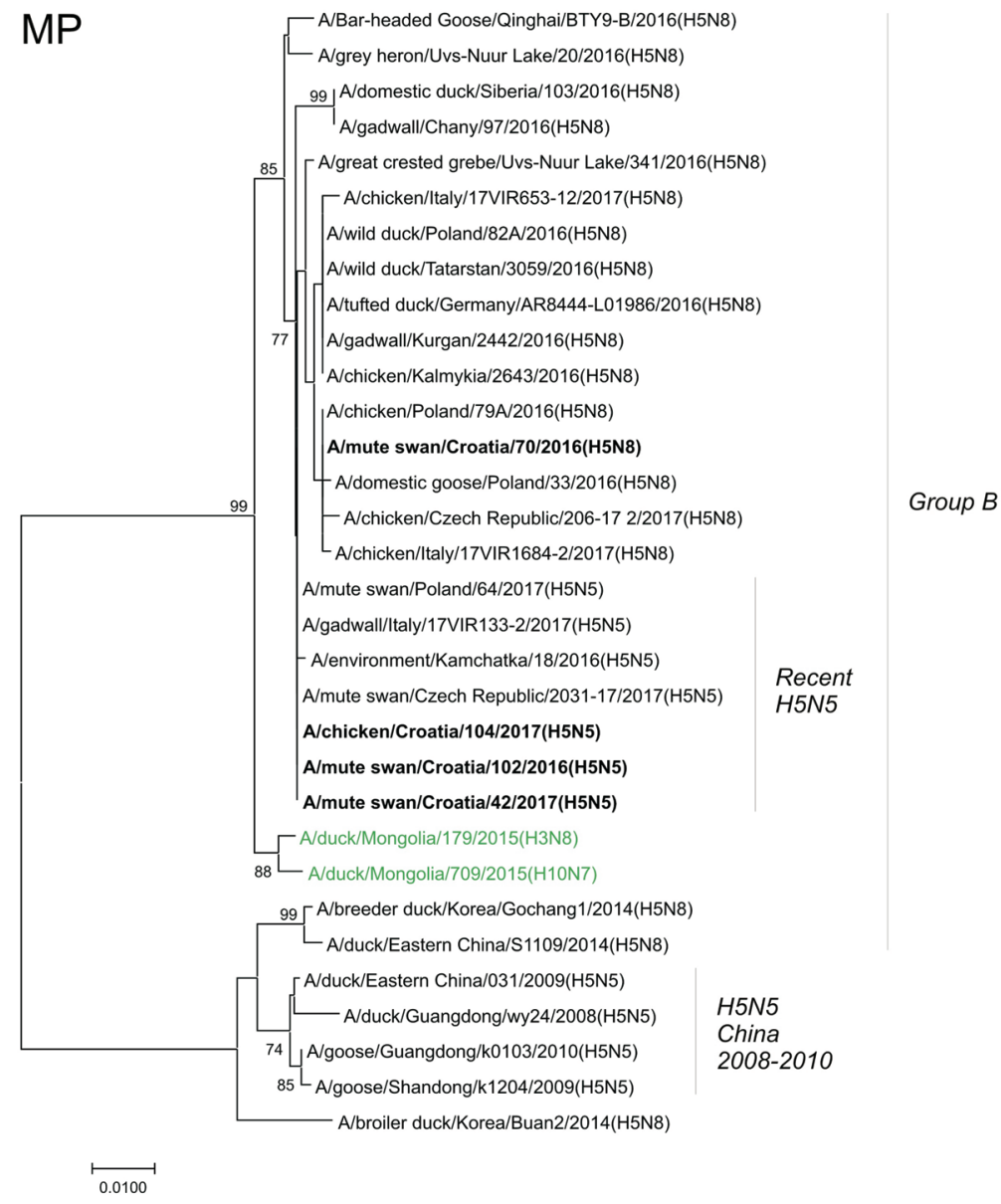

Fig. 8. Phylogenetic analysis of matrix (MP) gene segment for avian influenza virus isolates from Croatia and reference isolates of lineage A/Goose/Guangdong/1/96 clade 2.3.4.4 and related low pathogenic avian influenza viruses (LPAIV). LPAIV are indicated in green. Influenza virus sequences from Genbank and the GISAID EpiFlu ${ }^{\mathrm{TM}}$ database were used for comparison. Viruses that were sequenced in this study are indicated in bold. The evolutionary history was inferred using the Neighbor-Joining method in MEGA7 (KUMAR et al., 2016). The percentage of replicate trees in which the associated taxa clustered together in the bootstrap test (1000 replicates) are shown next to the branches $(>70 \%)$. The evolutionary distances were computed using the Maximum Composite Likelihood. Scale bar indicates nucleotide substitutions per site. 
V. Savić: Novel reassortant clade 2.3.4.4 avian influenza H5N5 virus in Croatia, 2016-2017

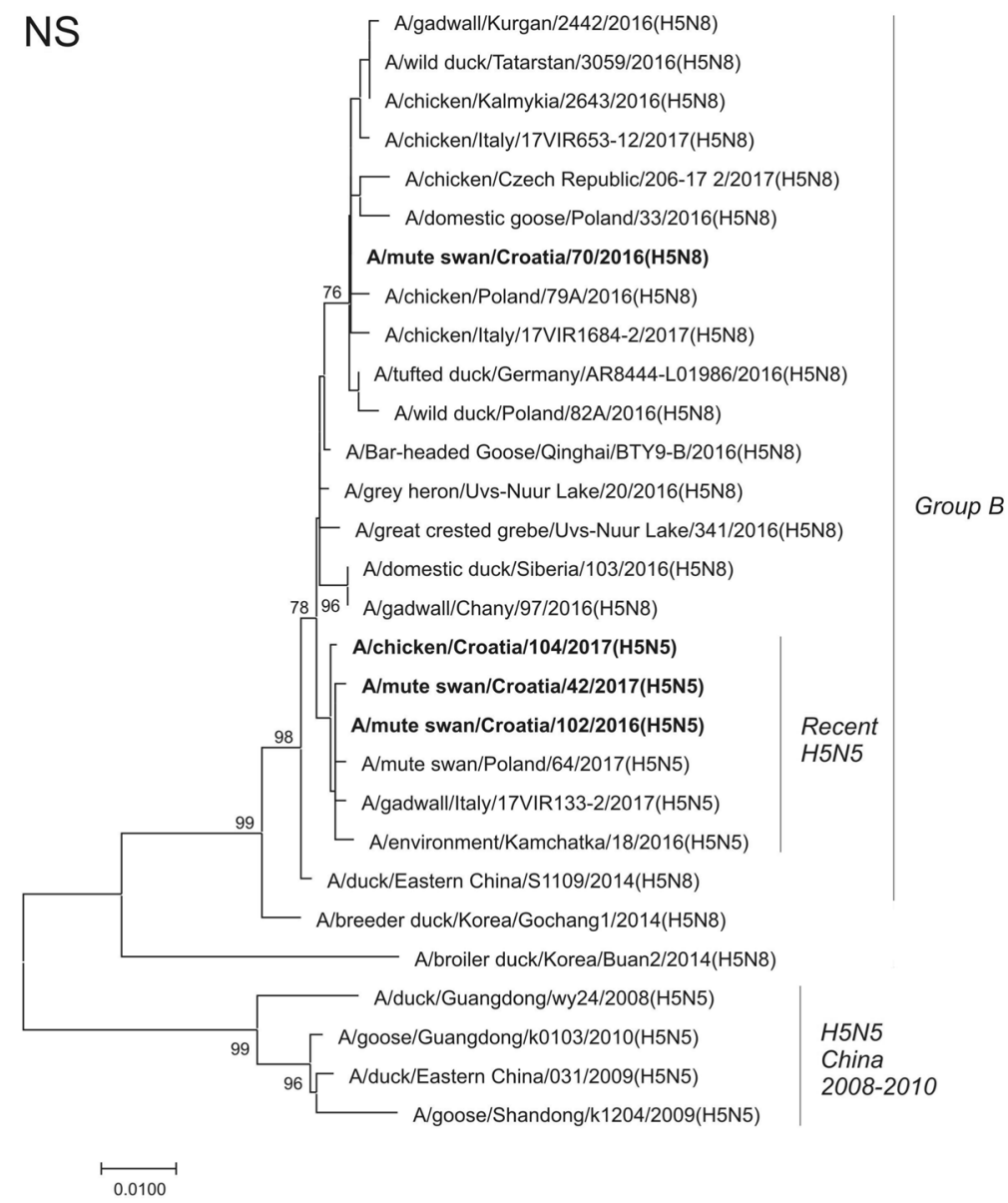

Fig. 9. Phylogenetic analysis of nonstructural (NS) gene segment for avian influenza virus isolates from Croatia and reference isolates of lineage A/Goose/Guangdong/1/96 clade 2.3.4.4. Influenza virus sequences from Genbank and the GISAID EpiFlu ${ }^{\mathrm{TM}}$ database were used for comparison. Viruses that were sequenced in this study are indicated in bold. The evolutionary history was inferred using the Neighbor-Joining method in MEGA7 (KUMAR et al., 2016). The percentage of replicate trees in which the associated taxa clustered together in the bootstrap test (1000 replicates) are shown next to the branches $(>70 \%)$. The evolutionary distances were computed using the Maximum Composite Likelihood. Scale bar indicates nucleotide substitutions per site. 


\section{Discussion}

HPAI virus subtype H5N8 was first confirmed in dead mute swans in east Croatia in late October 2016 and the epidemic spread within following winter months among wild birds throughout inland Croatia. The virus is closely related to novel reassortant clade 2.3.4.4 group B H5N8 virus which was detected in wild migratory birds at the Qinghai Lake, China and Russia-Mongolia border already in spring 2016 (LEE et al., 2017, LI et al., 2017), followed by detection in autumn in poultry in European Russia (MARCHENKO et al., 2017) and wild birds and poultry in other European countries (POHLMANN et al., 2017). This dissemination of the virus from Asia to Europe was attributed to aquatic bird migration, as was the case with $\mathrm{H} 5 \mathrm{~N} 8$ clade 2.3.4.4 group A virus when it spread worldwide in 2014-2015 by long-distance migratory birds (GLOBAL CONSORTIUM FOR H5N8, 2016). Although Croatian H5N8 index case virus Swn70-H5N8 is genetically closely related to the isolates from Russia-Mongolia border, the full genome sequence of this virus have shown that it clearly differs in two gene segments; polymerase basic (PB) 2 and NP. Similarly, German 2016 H5N8 virus could be clearly distinguished from the isolates from Russia-Mongolia in PA and NP segments (POHLMANN et al., 2017). According to phylogenetic tree topologies and the tree positions of these two viruses from Croatia and Germany as well as other recent H5N8 viruses (Figs 2-9) it is evident that several novel H5N8 reassortant viruses of clade 2.3.4.4 group B emerged and spread in wild birds and poultry within Asia and Europe in late 2016 and early 2017. These reassortment events have involved unknown number of LPAI viruses where at least two different LPAI viruses were involved in reassortment of each of PB2, PB1, PA and NP segments and at least one LPAI virus in reassortment of matrix (MP) segment.

Concurrently with numerous recent HPAI clade 2.3.4.4 H5N8 outbreaks in Croatia, three HPAI H5N5 outbreaks were caused by virus of the same clade, two of them in wild birds and one in poultry. Interestingly, although these two H5N5 isolates from wild aquatic birds were found in interval of 3 weeks and distance of $170 \mathrm{~km}$, in each case a H5N8 virus was detected in wild birds on the same day or two days earlier just 5 or $10 \mathrm{~km}$ away from each H5N5 outbreak, respectively (data partially shown in Fig. 1 and Table 1). This could have been due to reassortment of introduced H5N8 viruses with locally circulating HxN5 LPAI viruses. Similar scenario was documented in North America 2014-2015 after introduction of HPAI clade 2.3.4.4 group A H5N8 virus resulting in intercontinental reassortants $\mathrm{H} 5 \mathrm{~N} 1$ and $\mathrm{H} 5 \mathrm{~N} 2$ that contain $\mathrm{HA}$ segment of Asian origin $\mathrm{H} 5 \mathrm{~N} 8$ virus and NA segment of North America LPAI viruses (LEE et al., 2015). The reassortment event of Croatian H5N5 viruses could have occurred before introduction into Croatia as it was case with H5N8 reassortant initially detected in the Qinghai Lake and around Uvs-Nuur Lake in spring 2016 and which later spread across Asia and Europe. In such case the $\mathrm{H} 5 \mathrm{~N} 5$ virus could have spread from Asia as a subpopulation together with $\mathrm{H} 5 \mathrm{~N} 8$ virus by long-distance migratory birds. Finally, clade 2.3.4.4 H5N5 viruses that were reported to 
circulate in poultry in China 2008-2010 (LI et al., 2015; ZHAO et al., 2013) could have been unnoticed in wild birds and recently spread by long-distance migratory birds to Europe as a subpopulation of the introduced $\mathrm{H} 5 \mathrm{~N} 8$ virus.

In contrast to GD/96 H5N1 viruses, the novel clade 2.3.4.4 viruses generally have not caused human infections (DE VRIES et al., 2015). Nevertheless, novel reassortant clade 2.3.4.4 H5N6 virus causes lethal human infection (SHEN et al., 2016). It was pragmatic therefore to sequence the entire genome of all three recent isolates of the H5N5 reassortant virus to identify the origin of the virus and to identify eventual mutations that might influence viral phenotypic characteristics which may indicate adaptation to mammalian species or alter susceptibility to antiviral drugs. Of 104 single or collective mutations of importance, only 3 were found in recent Croatian H5N5 virus isolates (Table 2). In addition to polybasic cleavage site in the HA protein which is always present in HPAI viruses, mutations $\mathrm{T} 215 \mathrm{~A}$ in $\mathrm{M} 1$ protein and $\mathrm{P} 42 \mathrm{~S}$ in NS1 protein are associated to increased virulence in mice. None of the mutations related to increased affinity to human-type $(\alpha-$ $2,6)$ receptors and mammalian host adaptation were found, so the novel reassortant clade 2.3.4.4 H5N5 virus has typical avian virus traits with apparently no immediate threat to public health. Nevertheless, the virus is highly pathogenic for gallinaceous birds, which was confirmed by high IVPI (2.87) and poses a serious threat to the poultry industry.

Phylogenetic analysis of all 8 segments has revealed that the novel clade 2.3.4.4 H5N5 virus is not descent of the H5N5 viruses found in poultry in China 2008-2010 and belongs to the group B (Gochang like). It has undergone very similar reassortment process to the recent H5N8 viruses of the same clade, but with additional LPAI virus(es) involved. The NA segment shares high identity to recent Asian N5 LPAI viruses $(>98.5 \%$ identity to A/common redshank/Singapore/F83-2/2015[H9N5]). In addition to different NA subtype, involvement of further LPAI virus(es) in reassortments resulted in clusters of recent H5N5 strains located in separate branches in PB2, PB1, and NP segment phylogenetic trees (Figures 2, 3, and 6). The HA segment of recent H5N5 viruses also displays separate grouping from recent $\mathrm{H} 5 \mathrm{~N} 8$ viruses which might be due to a separate recent evolution. Both, H5N5 and H5N8 viruses share very similar NS segment to clade 2.3.4.4 group B HPAI H5N8 viruses identified in poultry in eastern China in 2014 (Fig. 9), which indicates their mutual origin, most likely in infected poultry in China. Although recent $\mathrm{H} 5 \mathrm{~N} 5$ and $\mathrm{H} 5 \mathrm{~N} 8$ viruses share common MP segment $(99.6 \%$ identity between Swn102-H5N5 and Swn70-H5N8), the MP segment discrete both of them from the HPAI H5N8 viruses identified in poultry in eastern China (Fig. 8). The MP segment was most likely acquired from LPAI viruses circulating in Mongolia (LEE et al., 2017; LI et al., 2017) before recent H5N5 viruses have separated from recent H5N8 viruses. Similarly, the PA segment of recent Croatian H5N5 isolates clusters with H5N8 viruses from Qinghai Lake, Russia-Mongolia border and some European countries, but is clearly different from their HA segment precursor (Fig. 4). It should be emphasized that H5N5 viruses with high 
homology ( $\geq 99.5$ identity) to the Croatian H5N5 isolates in all 8 segments have been concurrently detected in Italy and Poland but also in faecal sample of slaty-backed gull (Larus schistisagus) in Kamchatka, Russian Federation (Figs 2-9). It is reasonable to suggest that recent HPAI H5N5 viruses found in wild birds and poultry in Croatia most likely emerged in Asia as a reassortant from the same HA precursor virus in wild birds as for recent $\mathrm{H} 5 \mathrm{~N} 8$ viruses, and were introduced in Croatia by migratory wild birds probably by the same wild bird flyways as the recent H5N8 viruses.

\section{Acknowledgements}

The author gratefully acknowledges Prof. Ian Brown and Dr. Steve Essen from the EU/OIE/FAO Reference Laboratory for Avian Influenza, Animal and Plant Health Agency (APHA), Weybridge, UK, for determination of the intravenous pathogenicity index and GISAID submitters for influenza virus segments used in this study.

\begin{tabular}{|c|c|c|c|}
\hline Isolate ID & Isolate name & Submitting Lab & Authors \\
\hline EPI_ISL_224721 & $\begin{array}{l}\text { A/Bar-headed Goose/Qinghai/ } \\
\text { BTY9-B/2016 }\end{array}$ & $\begin{array}{l}\text { Wuhan Institute } \\
\text { of Virology }\end{array}$ & Chen, J. \\
\hline EPI_ISL_256307 & $\begin{array}{l}\text { A/chicken/ } \\
\text { Italy/17VIR1684-2/2017 }\end{array}$ & \multirow{3}{*}{$\begin{array}{l}\text { Istituto } \\
\text { Zooprofilattico } \\
\text { Sperimentale } \\
\text { Delle Venezie }\end{array}$} & \multirow{3}{*}{$\begin{array}{l}\text { Zecchin, B., Fusaro, A., Milani, A., } \\
\text { Schivo, A., Salviato, A., Zamperin, } \\
\text { G., Marciano, S., Ormelli, S., } \\
\text { Terregino, C., Monne, I. }\end{array}$} \\
\hline EPI_ISL_255184 & $\begin{array}{l}\text { A/chicken/ } \\
\text { Italy/17VIR653-12/2017 }\end{array}$ & & \\
\hline EPI_ISL_255189 & $\begin{array}{l}\text { A/gadwall/ } \\
\text { Italy/17VIR133-2/2017 }\end{array}$ & & \\
\hline EPI_ISL_240104 & A/chicken/Poland/79A/2016 & \multirow{4}{*}{$\begin{array}{l}\text { National } \\
\text { Veterinary } \\
\text { Research } \\
\text { Institut Poland, } \\
\text { PIWet-PIB }\end{array}$} & \multirow{4}{*}{ Swieton, E., Smietanka, K. } \\
\hline EPI_ISL_240102 & $\begin{array}{l}\text { A/domestic goose/ } \\
\text { Poland/33/2016 }\end{array}$ & & \\
\hline EPI_ISL_255917 & A/mute swan/Poland/64/2017 & & \\
\hline EPI_ISL_237921 & A/wild duck/Poland/82A/2016 & & \\
\hline EPI_ISL_237733 & $\begin{array}{l}\text { A/tufted duck/Germany/ } \\
\text { AR8444-L01986/2016 }\end{array}$ & $\begin{array}{l}\text { Friedrich- } \\
\text { Loeffler-Institut }\end{array}$ & Pohlmann, A. \\
\hline EPI_ISL_250920 & $\begin{array}{l}\text { A/mute swan/Czech } \\
\text { Republic/2031-17/2017 }\end{array}$ & $\begin{array}{l}\text { State Veterinary } \\
\text { Institute Prague }\end{array}$ & Nagy, A. \\
\hline EPI_ISL_247725 & $\begin{array}{l}\text { A/chicken/ } \\
\text { Kalmykia/2643/2016 }\end{array}$ & \multirow{4}{*}{$\begin{array}{l}\text { State Research } \\
\text { Center of } \\
\text { Virology and } \\
\text { Biotechnology } \\
\text { (VECTOR) }\end{array}$} & \multirow{4}{*}{$\begin{array}{l}\text { Susloparov, I., Goncharova, N., } \\
\text { Kolosova, N., Marchenko, V., } \\
\text { Ryzhikov, A. }\end{array}$} \\
\hline EPI_ISL_256298 & A/gadwall/Kurgan/2442/2016 & & \\
\hline EPI_ISL_247724 & $\begin{array}{l}\text { A/wild duck/ } \\
\text { Tatarstan/3059/2016 }\end{array}$ & & \\
\hline EPI_ISL_256301 & $\begin{array}{l}\text { A/environment/ } \\
\text { Kamchatka/18/2016 }\end{array}$ & & \\
\hline EPI_ISL_250231 & A/gadwall/Chany/97/2016 & \multirow{2}{*}{$\begin{array}{l}\text { WHO National } \\
\text { Influenza } \\
\text { Centre Russian } \\
\text { Federation }\end{array}$} & \multirow{2}{*}{$\begin{array}{l}\text { Sharshov, K., Sobolev, I., Li, X., } \\
\text { Fadeev, A., Egorova, A., Kotenko, A., } \\
\text { Komissarov, A., Vasin, A., Kurskaya, } \\
\text { O., Alexeev, A., Shestopalov, A. }\end{array}$} \\
\hline EPI_ISL_250238 & $\begin{array}{l}\text { A/domestic duck/Siberia/49 } \\
\text { feather/2016 }\end{array}$ & & \\
\hline
\end{tabular}


V. Savić: Novel reassortant clade 2.3.4.4 avian influenza H5N5 virus in Croatia, 2016-2017

\begin{tabular}{|c|c|c|c|}
\hline Isolate ID & Isolate name & Submitting Lab & Authors \\
\hline EPI_ISL_240672 & A/shoveler/Chany/82K/2014 & \multirow{4}{*}{$\begin{array}{l}\text { Research } \\
\text { Institute of } \\
\text { Experimental } \\
\text { and Clinical } \\
\text { Medicine }\end{array}$} & Sharshov, K., Sobolev, I., Li, X., \\
\hline EPI_ISL_224580 & $\begin{array}{l}\text { A/great crested grebe/Uvs- } \\
\text { Nuur Lake/341/2016 }\end{array}$ & & $\begin{array}{l}\text { Alikina, T., Glushenko, A., Kurskaya, } \\
\text { O., Kabilov, M., Alekseev, A., } \\
\text { Shestopalov, A. }\end{array}$ \\
\hline EPI_ISL_240677 & $\begin{array}{l}\text { A/domestic duck/ } \\
\text { Siberia/103/2016 }\end{array}$ & & $\begin{array}{l}\text { Sharshov, K., Kurskaya, O., Alexeev, } \\
\text { A., Sobolev, I., Alikina, T., Kabilov, } \\
\text { M., Shestopalov, A. }\end{array}$ \\
\hline EPI_ISL_234057 & $\begin{array}{l}\text { A/grey heron/Uvs-Nuur } \\
\text { Lake/20/2016 }\end{array}$ & & $\begin{array}{l}\text { Sharshov, K., Kurskaya, O., Sobolev, } \\
\text { I., Alekseev, A., Shestopalov, A. }\end{array}$ \\
\hline
\end{tabular}

\section{References}

ALEXANDER, D. J., I. CAPUA (2008): Avian influenza in poultry. World Poultry Sci. J. 64, 513-532.

ARRIOLA, C. S., D. I. NELSON, T. J. DELIBERTO, L. BLANTON, K. KNISS, M. Z. LEVINE, S C. TROCK, L. FINELLI, M. A. JHUNG, and the H5 Investigation Group (2015): Infection risk for persons exposed to highly pathogenic avian influenza A H5 virus-infected birds, United States, December 2014-March 2015. Emerg. Infect. Dis. 21, 2135-2140.

CENTERS FOR DISEASE CONTROL AND PREVENTION (2012): Influenza H5N1 genetic changes inventory: a tool for influenza surveillance and preparedness. [cited 2017 May 02]. http://www.cdc.gov/flu/pdf/avianflu/h5n1-inventory.pdf

DE VRIES, E., H. GUO, M. DAI, P. J..M. ROTTIER, F. J. M. van KUPPEVELD, C. A. M. de HAAN (2015): Rapid emergence of highly pathogenic avian influenza subtypes from a subtype H5N1 hemagglutinin variant. Emerg. Infect. Dis. 21, 842-846.

FEREIDOUNI, S. R., E. STARICK, C. GRUND, A. GLOBIG, T. C. METTENLEITER, M. BEER, T. HARDER (2009): Rapid molecular subtyping by reverse transcription polymerase chain reaction of the neuraminidase gene of avian influenza A viruses. Vet. Microbiol. 135, 253-260.

GLOBAL CONSORTIUM FOR H5N8 AND RELATED INFLUENZA VIRUSES (2016): Role for migratory wild birds in the global spread of avian influenza H5N8. Science 354, 213-217.

HOFFMANN, E., J. STECH, Y. GUAN, R. G. WEBSTER, D. R. PEREZ (2001): Universal primer set for the full-length amplification of all influenza A viruses. Arch. Virol. 146, 22752289.

KUMAR, S., G. STECHER., K. TAMURA (2016): MEGA7: Molecular evolutionary genetics analysis version 7.0 for bigger datasets. Mol. Biol. Evol. 33, 1870-1874.

LEE, D. H., M. K. TORCHETTI, K. WINKER, H. S. IP, C. S. SONG, D. E. SWAYNE (2015): Intercontinental spread of Asian-origin H5N8 to North America through Beringia by migratory birds. J. Virol. 89, 6521-6524.

LEE, Y. J., H. M. KANG, E. K. LEE, B. M. SONG, J. JEONG, Y. K. KWON, H. R. KIM, K. J. LEE, M. S. HONG, I. JANG, K. S. CHOI, J. Y. KIM, H. J. LEE, M. S. KANG, O. M. 
JEONG, J. H. BAEK, Y. S. JOO, Y. H. PARK, H. S. LEE (2014): Novel reassortant influenza A(H5N8) viruses, South Korea, 2014. Emerg. Infect. Dis. 20, 1087-1089.

LEE, D. H., K. SHARSHOV, D. E. SWAYNE, O. KURSKAYA, I. SOBOLEV, M. KABILOV, A. ALEKSEEV, V. IRZA, A. SHESTOPALOV (2017): Novel reassortant Clade 2.3.4.4 avian influenza A(H5N8) virus in wild aquatic birds, Russia, 2016. Emerg. Infect. Dis. 23, 359-360.

LI, M., H. LIU, Y. BI, J. SUN, G. WONG, D. LIU, L. LI, J. LIU, Q. CHEN, H. WANG, Y. HE, W. SHI, G. F. GAO, J. CHEN (2017): Highly Pathogenic Avian Influenza A(H5N8) Virus in wild migratory birds, Qinghai Lake, China. Emerg. Infect. Dis. 23, 637-641.

LI, O. T., I. BARR, C. Y. LEUNG, H. CHEN, Y. GUAN, J. S. PEIRIS, L. L. POON (2007): Reliable universal RT-PCR assays for studying influenza polymerase subunit gene sequences from all 16 haemagglutinin subtypes. J. Virol. Methods 142, 218-222.

LI, Q, X. WANG, Z. GAO, Z. SUN, Z. CUI, Z. DUAN, J. LI, M. GU, X. WANG, J. HU, X. LIU, $X$. LIU (2015): Novel reassortant H5N5 viruses bind to a human-type receptor as a factor in pandemic risk. Vet Microbiol. 175, 356-361.

MARCHENKO, V. Y., I. M. SUSLOPAROV, A. B. KOMISSAROV, A. FADEEV, N. I. GONCHAROVA, A. V. SHIPOVALOV, S. V. SVYATCHENKO, A. G. DURYMANOV, T. N. ILYICHEVA, L. K. SALCHAK, E. P. SVINTITSKAYA, V. N. MIKHEEV, A. B. RYZHIKOV (2017): Reintroduction of highly pathogenic avian influenza A/H5N8 virus of clade 2.3.4.4. in Russia. Arch. Virol. 162, 1381-1385.

NEUMANN, G., H. CHEN, G. F. GAO, Y. SHU, Y. KAWAOKA (2010): H5N1 influenza viruses: outbreaks and biological properties. Cell Res. 20, 51-61.

OIE (2015): Avian influenza (infection with avian influenza viruses). In: OIE Terrestrial Manual (NB: Version adopted in May 2015), Chapter 2.3.4, 1 -23.

OLSEN, B., V. J. MUNSTER, A. WALLENSTEN, J. WALDENSTROM, A. D. OSTERHAUS, R. A. FOUCHIER (2006): Global patterns of influenza a virus in wild birds. Science 312, 384-388.

POHLMANN, A., E. STARICK, T. HARDER, C. GRUND, D. HÖPER, A. GLOBIG, C. STAUBACH, K. DIETZE, G. STREBELOW, R. G. ULRICH, J. SCHINKÖTHE, J. P. TEIFKE, F. J. CONRATHS, T. C. METTENLEITER, M. BEER (2017): Outbreaks among wild birds and domestic poultry caused by reassorted Influenza A(H5N8) clade 2.3.4.4 viruses, Germany, 2016. Emerg. Infect. Dis. 23, 633-636.

SHEN, Y., C. KE, Q. LI, R. YUAN, D. XIANG, W. JIA, Y-D. YU, L. LIU, C. HUANG, W-B. QI, R. SIKKEMA, J. WU, M KOOPMANS, M LIAO (2016): Novel reassortant avian influenza A(H5N6) viruses in humans, Guangdong, China, 2015. Emerg. Infect. Dis. 22, 1507-1509.

SLOMKA, M. J., T. PAVLIDIS, J. BANKS, W. SHELL, A. McNALLY, S. ESSEN, I. H. BROWN (2007a): Validated H5 Eurasian real-time reverse transcriptase-polymerase chain reaction and its application in H5N1 outbreaks in 2005-2006. Avian Dis. 51, 373-377.

SLOMKA, M. J., V. J. COWARD, J. BANKS, B. Z. LÖNDT, I. H. BROWN, J. VOERMANS, G. KOCH, K. J. HANDBERG, P. H. JØRGENSEN, M. CHERBONNEL-PANSART, V. JESTIN, G. CATTOLI, I. CAPUA, A. EJDERSUND, P. THORÉN, G. CZIFRA (2007b): 
Identification of sensitive and specific avian influenza polymerase chain reaction methods through blind ring trials organized in the European Union. Avian Dis. 51, 227-234.

SPACKMAN, E., D. A. SENNE, T. J. MYERS, L. L. BULAGA, L. P. GARBER, M. L. PERDUE, K. LOHMAN, L. T. DAUM, D. L. SUAREZ (2002): Development of a realtime reverse transcriptase PCR assay for the type A influenza virus and the avian $\mathrm{H} 5$ and $\mathrm{H} 7$ haemagglutinin subtypes. J. Clin. Microbiol. 40, 3256-3260.

WORLD HEALTH ORGANIZATION (WHO) (2015): Evolution of the influenza A(H5) haemagglutinin: WHO/OIE/FAO H5 Working Group reports a new clade designated 2.3.4.4 (2015); [cited 2017 May 02] www.who.int/influenza/gisrs_laboratory/h5_nomenclature clade2344/en/

WORLD HEALTH ORGANIZATION/WORLD ORGANISATION FOR ANIMAL HEALTH/FOOD AND AGRICULTURE ORGANIZATION (WHO/OIE/FAO) H5N1 EVOLUTION WORKING GROUP (2014): Revised and updated nomenclature for highly pathogenic avian influenza A (H5N1) viruses. Influenza Other Respi Viruses 8, 384-388.

ZHAO, K., M. GU, L. ZHONG, Z. DUAN, Y. ZHANG, Y. ZHU, G. ZHAO, M. ZHAO, Z. CHEN, S. HU, W. LIU, X. LIU, D. PENG (2013): Characterization of three H5N5 and one H5N8 highly pathogenic avian influenza viruses in China. Vet. Microbiol. 163, 351-357.

Received: 9 May 2017

Accepted: 8 June 2017

\section{SAVIĆ, V.: Nova presloženica virusa A(H5N5) filogenetske grane 2.3.4.4. u divljih ptica i peradi, Hrvatska, 2016-2017. Vet. arhiv 87, 377-396, 2017. \\ SAŽETAK}

Visokopatogeni virusi influence ptica (VPVIP) uzrokuju i do 100\% uginuća u osjetljivih vrsta peradi, ali predstavljaju i prijetnju ljudima, posebno virusi loze A/goose/Guangdong/96-like (GD/96). Pojava novih virusa VPVIP u ptica selica je od značaja zbog mogućeg širenja virusa tijekom migracija. Krajem 2016. godine u divljih ptica i domaće peradi u Hrvatskoj je otkrivena nova presloženica virusa influence ptica podtipa H5N5 loze GD/96, filogenetske grane 2.3.4.4, skupine B, istodobno s otkrivanjem brojnih virusa podtipa H5N8 iste filogenetske grane i skupine. Određivanje slijeda nukleotida cijelog genoma izolata iz prvog slučaja s virusom podtipa H5N8 (listopad 2016.) i svih triju izolata virusa podtipa H5N5 (prosinac 2016. - veljača 2017.) pokazalo je da je nova presloženica virusa podtipa H5N5 najvjerojatnije nastala u Aziji kao posljedica složenog procesa preslagivanja VPVIP podtipa H5N8 nakon što je potonji virus već bio nazočan u populaciji divljih ptica. Istodobni nalaz oba virusa podtipova H5N5 i H5N8 na istim mjestima u Hrvatskoj pokazuje da je nova presloženica virusa podtipa H5N5 unesena iz Azije kao potpopulacija virusa podtipa H5N8 istim selidbenim putovima divljih ptica. Iako nova presloženica virusa podtipa H5N5 posjeduje hemaglutinin loze GD/96, genom ovog virusa ima obilježja tipična za ptičje viruse influence. Osim mutacija T215A u M1 proteinu i P42S u NS1 proteinu koje su povezane s povećanom virulencijom za miševe, nije nađena niti jedna od mutacija povezanih s povećanim afinitetom prema receptorima humanog tipa $(\alpha-2,6)$ i prilagodbe prema sisavcima. Ipak, virus predstavlja ozbiljnu prijetnju peradarstvu, budući da je visoka patogenost za galiformne ptice potvrđena visokim intravenskim indeksom patogenosti $(2,87)$.

Ključne riječi: influenca ptica, visokopatogeni virus, H5N5, presloženica, sekvencija cijelog genoma 